Ewa Drab

10.15290/cr.2017.18.3.03

University of Silesia in Katowice

\title{
Time and History at the Crossroads of Polish Imaginary Genres. Krzysztof Piskorski's Czterdzieści i cztery and Andrzej Pilipiuk's Operacja Dzień Wskrzeszenia
}

\begin{abstract}
The present article is an attempt to examine the meaning of time and history in Polish steampunk and science fiction, where time-related concepts constitute the foundations of the genres. As it locates steampunk in a precise period of the 19th century, history determines its definition, regardless of the nationality of the author. What differs in the Polish variation of steampunk is the spatial, not temporal, frame, a modification clearly visible in Krzysztof Piskorski's Czterdzieści i cztery (2016), where the Polish fight for independence is presented through the prism of the protagonist's journey across European countries. In science fiction, the determinant factor is time in time travel, as well as the historical perspective of the idea of progress. The presentation of Andrzej Pilipiuk's Operacja Dzień Wskrzeszenia (2006) proves the importance of time in science fiction and points to the paradoxes which SF authors have to face. All in all, the examination of both novels shows the difference in the approach adopted by two 21st century Polish writers towards different, yet similar, concepts.
\end{abstract}

Key words: History, time, Krzysztof Piskorski, Andrzej Pilipiuk, Polish fantasy, steampunk, science-fiction.

\section{Introduction}

The flow of time, history and the prediction of the future constitute an important part of the narratives and world-building in fantasy, science-fiction and kindred genres. Concepts related to history are employed even by the representatives of fantasy and science fantasy, in which the question of time is not necessarily raised. Fantasy is typically set in an imaginary version of the Middle Ages. In other words, history serves as a source of inspiration for a construction of fantasy universes, such as the Continent from the stories about The Witcher (1993-1999) by Andrzej Sapkowski. In science fantasy, the scientific part may refer to a time machine which transports the characters to a magical land, as happens, for example, in Witch World (1963) by Andre Norton. Nevertheless, it is steam- 
punk and science fiction which explore the notions of time and history in depth. Steampunk draws from history, or from 19th century history to be more precise, to tackle the topics of change and revolution, whereas science fiction is a means of interrogating progress and technological development, including time travel and its ensuing paradoxes. In the Polish variations of the said genres, clear examples of their close connections with history and time are provided by Krzysztof Piskorski in Czterdzieści i cztery (2016) and by Andrzej Pilipiuk in Operacja Dzień Wskrzeszenia (2006). However, before embarking on the analysis of these particular relations in the above-mentioned novels, it is crucial to ponder upon the role of history and time within steampunk and science fiction in greater detail. Consequently, the examination of each text will be preceded by a short review of theory.

\section{History in Steampunk}

History is rooted in the very nature of steampunk literature. Definitions, even if dissonant, usually point to the given historical period which constitutes both the subject and the backdrop of the genre. The Victorian era, with its process of industrialization and social unrest, fuels steampunk and allows the literature to explore universal truths. K.W. Jeter, perceived as the originator of the name of the genre, called what later became steampunk Victorian fantasies (Mielke, LaHaie 2015: 243), which actually illustrates well the clash between the historical context of the genre and its imaginary side. The purpose of steampunk is to "explore the past, mainly the 19th century, by describing and researching the consequences of the alternative and hyperbolized process of industrial revolution " (Lemann 2015: 133). Not only does steampunk refer to history, but it also reinvents it to pinpoint aspects that reflect the maladies of the present. The representatives of the genre need to be able to delve into history in order to manipulate it and to reshape meanings in ways that illuminate 21 st century issues and dangers.

The phase of acquiring the necessary knowledge of the given period should be followed by the stage of picking and emphasising the elements which could easily undergo this transformation process. The re-shaping of the selected aspects of 19th century history becomes an intrusion of the imagination and an interpretation of the influence history exercises on the subsequent periods. In effect, steampunk authors combine “...what is known and what is strange" (Mielke, LaHaie 2015: 244) to see the past in the new light and draw fresh conclusions about the potential direction in which the present is moving. The adoption of a new perspective is possible thanks to the rebellious character of steampunk literature. The approach becomes visible in another definitional attempt to explain what the genre represents, which would be "past technologies (steam) [...] that govern alternative settings [...] in order to critique and/or rebel (punk) against social, political, and cultural ideologies of the past, the present, and the future" (Mielke, LaHaie 2015: 244). On the one hand, industrial development, by deeply impacting upon society, plays a crucial role in the steam-

1 “...eksploruje przeszłość, głównie wiek XIX, opisując i badając konsekwencje alternatywnego i zhiperbolizowanego w stosunku do rzeczywistego przebiegu rewolucji przemysłowej...” (all the translations of Polish sources are mine). 
punk take on history, but these are all revolutionary turns and breakthroughs which allow for a contemporary commentary. On the other hand, the combination of history and attractive fantasy alternatives provides the reader with entertainment and may induce them to explore real history in order to be able to distinguish between a crafty illusion and facts. Yet, the critique makes the reader ponder upon the network of interconnections between the role of an individual and the collective, and on how particular decisions give rise to a certain course of history. Therefore, the reader is given an opportunity to deliberate further on the impact of the past upon the present.

By adopting the perspective based on a general historical reflection, it is possible to understand steampunk outside of the Victorian period. As a genre which transforms and embraces elements of diverse origin, it may be easily re-shaped to espouse the local context or at least a different one in comparison to the traditional take on the Victiorian era. Hence, authors use the poetics of stempunk and the 19th century setting, as well as the genre being prone to expressing rebellion against the social and political order to comment on the important events within their own culture. Polish steampunk has developed in a way which constitutes a realization of the said model, namely by referring to Polish history, parallel to the circumstances of the Victorian period. Natalia Lemann (2015: 136) points out that the Polish version of steampunk could be seen as an attempt to adapt what is global to the local context, or to Polish history and social conditions.

Lemann $(2015: 136,139)$ underlines the fact that the perspective changes as well: while the British occupy the position of a colonizer, the Polish face the fate of the colonized. It is so because Polish steampunk is centered upon the period of partitions, when the country was divided between and occupied by Austria, Prussia and Germany. Therefore, Polish authors explore the revolutionary character of steampunk literature and frequently focus on the 19th century national insurgences and Poland's fight for independence. Clearly, the historical core of steampunk becomes more political, and even the construction of surprising machines and inventions is determined by political choices. Moreover, Polish steampunk confronts different ideologies and approaches towards the invaders. As a result, the genre becomes, at least partially, a historical reflection on the juxtaposition of revolution and dialogue (Lemann 2015: 145). The above-mentioned aspects of Polish steampunk are visible in the most popular oeuvres by Krzysztof Piskorski and Andrzej W. Sawicki.

Apart from adapting the genre's tropes to a local context, the writers move steampunk literature aesthetics to a different culture as they wish to avoid its stagnation. The steampunk traits are often introduced into a story representing another related genre, for example fantasy, and, furthermore, embedded in a culture which constitutes a variation of an existing non-English and non-Victorian culture, or which has been entirely invented by the author. Jay Kristoff's Stormdancer (2012) delivers a good illustration of the former by incorporating steampunk tropes in an alternative fantasy Japan-like realm, whereas China Miéville's Perdido Street Station (2000) combines steampunk elements with a setting of an imaginary city, which could be associated with urban fantasy. In his creation, a reference to steampunk, as well as to other aesthetics, may also offer "a way of foregrounding possibilities for radical change" (Ganapathiraju 2012: 3), where such possibilities emphasize the potential of steampunk as a genre. Unfortunately, depriving steampunk of the histori- 
cal focus limits its impact and reduces it to a form of diversification aimed at making the narrative more attractive to the reader, even if it proves the genre's susceptibility to hybridization, which means that steampunk elements can be easily inserted into the framework of other similar genres. In the context of Polish steampunk, the importance of history is visible, for example in the work of Krzysztof Piskorski, the pioneer of the Polish steampunk variation. His books also prove that in the Polish texts the fight for independence remains a pivotal concept.

\section{Alternative Histories in Czterdzieści i cztery}

Krzysztof Piskorski's Czterdzieści i cztery is a 2016 steampunk-fantasy hybrid novel centered upon the adventures of a Polish spy, Eliza Żmijewska, and set within a frame of multiple alternative versions of Europe. The protagonist is haunted by a tumultuous past, including her participation in the 1830 November Uprising against Russia at the side of Emilia Plater, a captain of the Polish insurgent forces. The reader follows her steps when, fourteen years later, Eliza embarks on a dangerous mission to find and murder a British entrepreneur of Polish origins, Konrad Załuski. In order to complete her task, the protagonist attempts to travel to London by means of a teleport gate, whose copies have been installed in various points in Europe and aimed at connecting parallel realities. Because of numerous complications and hardships, Eliza journeys from London to revolutionary Paris and, subsequently, to Cracow at the time of the partition and Poland's submission to Austria, Russia and Prussia, which started in 1772 and ultimately lasted until the restoration of the country's sovereignty in 1918. During her trials and tribulations, Eliza faces internal moral conflicts, regarding personal and national loyalty, and is confronted with dangers as well as with the opportunities offered by the scientific discovery of alternative worlds. The introduction of parallel Europes permits the author to play with the concepts of time and history. Consequently, Piskorski draws abundantly on the traditions of science fiction, readily employs steampunk tropes, and refers to Slavic imagery by stitching the aforementioned elements together with the use of Polish history and culture.

The author introduces into the novel the most important steampunk tropes with virtuosity and ease. Indeed, Piskorski has experience in the creation of steampunk plots, as he demonstrated this particular ability prior to Czterdzieści i cztery. Natalia Lemann (2015: 138) points to his two-volume Zadra (2008) as the first undiluted Polish steampunk novel. The story presented in the books accurately illustrates the author's style, which moulds the narrative in Czterdzieści i cztery as well. In other words, Piskorski combines alternative European history with the real Polish endeavours of regaining independence and with the fantasy / SF concept of parallel realities, which manifests itself through the discovery of the New Europe, accessible via portals created with the use of ether technology. Moreover, the number of parallel realities is multiplied to infinity, where each can be accessed through the ether gates set in slightly different positions.

The multitude of alternative settings justifies all possible transformations of history as the reader knows it. Piskorski exploits history and reconfigures it to achieve a given goal, but remains respectful in reference to the actual turn of events in the real history of Poland and Europe. The approach towards the concept of the co-existence of universes within the world of the novel leads 
to a self-aware, self-mocking ending. Condemned to a solitary existence away from the troubles of the country she used to know and fight for, the protagonist hides in the only timeline where she can avoid meeting Konrad Załuski. An enthusiastic young journalist pays her a visit to write an article about her remarkable story. Eliza shows him a book she was offered by the representatives of an insectoid nation, a gift which has ultimately saved her life. The insect-like people, thanks to her help in obtaining the ether technology, progressed greatly in an alternative timeline, devised a method of traveling in time and, consequently, came from the future in order to warn their friend. The book recounts all of Eliza's adventures and experiences, including the conversation with the journalist. By describing the image from the cover, the author suggests that the said book is in fact Piskorski's Czterdzieści i cztery, which implies the existence of separate multiple timelines, including one for the author and one for the reader, and lends credence to the realities of the events presented in the novel. Piskorski's heroine comments on the origins of the book by saying it comes from a different, less civilized Europe with different time and history, hence the poor quality of paper and terrible language ${ }^{2}$ (Piskorski 2016: 533). Furthermore, she stresses the problem of the unequal development of the parallel histories, thus delivering both a justification for the interactions between the timelines and an indication of how the multiverse functions.

Piskorski plays easily with the notions of time and history by interlacing various threads of divergent realities. But what references to the real history of Poland and Europe does the author use and in what way does he reshape them? Interestingly, Czterdzieści i cztery not only adopts steampunk aesthetics to make them match a different historical background and fit the Polish context, but also merges the elements of traditional steampunk set in the Victorian era with the local variation. The said adjustment is possible because the author makes Eliza reside for several weeks in London, where she encounters real historical figures and shows the reader around the steampunk version of the British capital. The boldest use of a real person from the history of British culture is connected to one of the missions the protagonist burdens herself with. Eliza searches for an encoded message regarding her task of assassinating Załuski, but in fact finds more than one. Curious as to what the nature of other conspiracies is, she deciphers the password and heads to the meeting of a secret organization. This particular thread of the story refers to the poets of the pre-Victorian movement. The first indication is the password itself, namely Ozymandias, meaning the title of the famous sonnet written by Percy Bysshe Shelley, one of the greatest Romantic poets. Furthermore, Piskorski (2016: 134) pinpoints the character of the chapter and the part of the story by introducing into the text a translated citation from the sonnet.

However, steampunk authors do not limit their creation only to references, such as a well-known poem. The common tendency is to include a historical figure as an active character. As a result, in Czterdzieści i cztery, Eliza decrypts not only the title of Shelley's sonnet, but also meets one of the

2 “ ...nie wszystkie Europy żyją w jednym czasie. Istnieją nastawy, które prowadzą do miejsc, gdzie historia stoi na innym stopniu rozwoju. To książka z jednego z takich światów. Z mniej cywilizowanej epoki. Stąd, proszę wybaczyć, fatalny papier. I naprawdę okropny język”. 
other representatives of the movement in person, namely George Gordon, Lord Byron. In Piskorski's version (2016: 134), Byron, as a wheelchair-bound invalid, occupies the position of a leader of a secret association operating against the ether technology, which allegedly causes terrible mutations. Eliza, an amateur poet herself, is both thrilled to meet a living legend and overwhelmed by the discovery of the association (Piskorski 2016: 133). Nevertheless, references to Shelley and Byron, both advocates of freedom and justice in real history and in the anti-ether alternative presented in Czterdzieści i cztery, are accompanied by others as well. At the beginning of the chapters or within the text, the author introduces citations from famous poems or transforms them in a way which suggests an alternative provenance, with the applicable annotation regarding the implemented changes. Among the authors Piskorski $(2016: 102,109)$ refers to are, for example, William Wordsworth and William Blake. The first instance is used in order to create the atmosphere of early 19th century England and to portray Eliza as an educated woman and a poetry enthusiast. Inspired by an encounter with a poor boy, she is attempting to write a poem about his misfortune when she remembers a similar poem by Wordsworth, namely We Are Seven (1798). Another citation from a poem, this time London (1794) by William Blake, introduces a new chapter. Since it presents the adventures the protagonist is to have in the British capital, Blake's poetic description of the city, bleak and oppressive, prepares the reader for what is to enfold in the later part of the chapter and it grounds the narrative in the period.

Piskorski refers to historical figures, mainly to artists and poets, but also to politicians and rulers, in the Polish context as well. In the afterword, the author (2016: 539-547) draws attention to the fact that he has used numerous references to Polish history and culture, and would like to encourage readers to learn more about the characters who really existed and events which became a source of inspiration for the story presented in the novel. Therefore, English Romanticism is balanced with examples of Polish Romanticism, with the introduction of Adam Mickiewicz, Juliusz Słowacki and their literary work. The author even underlines the contact between Adam Mickiewicz and Lord Byron: "Eliza knew that George Byron was corresponding with Adam Mickiewicz, who had translated many of his works into Polish. Apparently, Adam, like Juliusz Słowacki, played a game of his own"3 (Piskorski 2016: 136). Both Słowacki and Mickiewicz are presented not only as great poets, but also as conspirators in the Polish fight for independence. Piskorski uses them as characters whom Eliza actually meets and, furthermore, their poems serve as a commentary to and a background of the story. Słowacki assigns Eliza to assassinate Konrad Załuski and, in the time of riots, offers her shelter: “...Eliza wondered whether among peaceful, rich bourgeois, far from the rumble of gunshots, it was easy for him to write about the philosophy of genesis, bloody revolutions and Zeitgeist"4 (Piskorski 2016: 374). Thus, the author alludes to Słowacki's real work and philosophy.

3 “Eliza wiedziała, że George Byron korespondował z Adamem Mickiewiczem, który przełożył na polski wiele jego dzieł. Widocznie Adam, podobnie jak Juliusz Słowacki, prowadził jakąś własną grę”.

4 “...Eliza zastanowiła się, czy między spokojnymi, bogatymi mieszczanami, daleko od huczących wystrzałów, łatwo było mu pisać o genezyjskiej filozofii, krwawych rewolucjach i Duchu Dziejów”. 
The protagonist encounters Adam Mickiewicz in Cracow, when she desperately searches for Załuski. To lend weight to the character, the author refers to Mickiewicz's poems. Eliza has written a letter to the master poet in order to enumerate all the historical imprecisions he committed in Śmierć pułkownika (1837), a poem about the November Uprising leader, Emilia Plater (Piskorski 2016: 476, Dzieje.pl 2017: online). The author (2016: 260-261) cites the poem earlier in the novel as a reminder of the events that obsess Eliza. In the prologue of the story the reader learns that Eliza fought in the November Uprising at the side of Emilia Plater, her dear friend and role model. The uprising takes place a year later than in reality, probably to justify the fantasy and steampunk modifications to historical events. In the alternative version, the forces led by Plater are massacred by otherworldy creatures controlled by Russians, whereas Eliza leaves her friend to die. In reality, Emilia Plater fell ill during the insurgence and died despite the treatment she had received (Dzieje. pl 2017: online). What is interesting is that Piskorski transforms the poems, Mickiewicz's Śmierć putkownika and Słowacki's Oda do wolności (1830) (2016: 154), to stress the fact that various timelines exist and to adapt the historical poetry to the requirements of the steampunk world. Nevertheless, he does not interfere with the citation from Dziady Part III (1832), from which comes the title of the book (Piskorski 2016: 499).

\section{Time in Science-fiction}

As steampunk merges often with other genres, it can also be coupled with science fiction. Such a combination allows for an exposition of both time and history. It is visible in the opening volume of Mark Hodder's book series Burton and Swinburne, entitled The Strange Affair of Spring Heeled Jack, where the eponymous character travels in time back to the England of the Victorian era and triggers an alternative course of events. In short, a science fiction concept, namely time travel, enables the author to create a steampunk archetypal story, with multiple references to the Industrial Revolution and historical figures, such as one of the favourite inventors of steampunk writers, Charles Babbage. The same pattern is employed in Piskorski's Czterdzieści i cztery. It clearly shows the meaning of the time travel concept within the framework of the science fiction genre and beyond it.

If history is located at the heart of steampunk, time determines science fiction. Katarzyna Gadomska (2002: 22) claims that time is an obligatory component of every SF text, and the focus on time leads to the topic of time travel, whether it refers to the portrayal of future societies, i.e. a metaphorical excursion in time, or to the physical movement between moments in time, meaning the literal travelling on a given timeline or jumping between different timelines. Gadomska (2002: 23-24) provides a review of different methods of time travelling devised by numerous authors, not only of contemporary science fiction, but also of the pioneering or precursory work in the genre. Upon a short inspection, it is possible to conclude that the initial strategies were simple, for example, the excursion in time could be induced with the use of drugs. Nevertheless, the most common system of time travel in science fiction is a time machine, whose name and rules of functioning vary depending on the author's decision or imagination, and the actual technologies available at the time. The close description of such processes is, however, mostly tackled by the authors of hard 
science fiction, which gives space for detailed scientific explanations, taken for granted in texts focused on the futuristic story rather than on the intricacies of technological speculations.

Before pondering the nature of time travel and its possible ramifications, Sara Bernstein (2015: 158) provides a simple definition of her study subject by claiming that "time travel occurs when an object or a person is relocated in time through means other than continuing to exist," which clearly alludes to the science fictional exploitation of time machines and other transportation methods. What is more, Bernstein analyzes different modes of time travel, lending focus more to time-consuming, lengthy time travel, where the characters involved have to experience a long journey, and merely mentioning for comparison purposes so-called instantaneous time travel, where the travellers relocate promptly to their destination in the next moment on the timeline.

Nonetheless, regardless of the variation of time travel, the sole notion of the physical change of location within time, being as much a futuristic as a philosophical question, nurtures science fiction. Time travel should be perceived as physical since it usually does not reverse the process of growing old or accelerate it, but literally relocates the protagonist within their lifespan. It results in "doubling" the character, creating the co-presence of both their young and old versions. Time travel may also be understood as a method of relocating the traveller beyond their life, to eras that would not be normally accessible to them, be it in the past or in the distant future. Whichever it is, time travel remains one of the core concepts of science fiction because it opens a path towards possibilities. The genre centers upon the possibilities presenting themselves at the present moment or in the future. Moreover, it concentrates on the repercussions of progress, mainly technological and scientific, but also social and emotional, whether the (d)evolution is observed starting back in the past or now. Time is needed in order to be able to examine the consequences of progress or regress and, hence, it constitutes both subject matter and the analytical tool of science fiction.

While discussing the nature of science fiction, researchers and academics tend to deliberate not only upon the concept of time travel, but also on the related paradoxes. David Lewis (1976: 145), while analysing the question of time travel from the philosophical point of view, observes that science fiction authors are frequently more interested in the effect of time travel than in the logic of a valid explanation of the process. The philosopher is, on the other hand, invested in examining the contradictions which emerge from the attempts to understand the concept of time travel. Therefore, Lewis (1976: 145) responds to the question of the meaning of time travel with the following words:

Inevitably, it involves a discrepancy between time and time. Any traveler departs and then arrives at his destination [...]. But if he is a time traveler, the separation in time between departure and arrival does not equal the duration of his journey [...]. How can it be that the same two events, his departure and his arrival, are separated by two unequal amounts of time?

Apparently, an attempt to understand the process of time travel and its use within the framework of science fiction leads to the analysis of various paradoxes contradicting the logic of the concept. The problem of the lapse of time between the departure and arrival of the traveller, which 
could be explained thanks to the theory of spatiotemporal dimensions, is only one of several timerelated science fictional paradoxes. Lewis (1976: 148) delves into the grandfather paradox, connected with the question of changing the past, often the premise for many science fiction texts. On the one hand, the past has already happened, hence, it is impossible to manipulate it. But, on the other hand, a time traveller should be easily capable of doing anything that the other people met at the moment which the traveller has reached are capable of. Nonetheless, if he or she does something as radical as killing their grandfather, they may even cease to exist, if the grandfather has not yet fathered their parent. But if they no longer exist, they cannot travel in time and kill the grandfather in the first place.

A similar problem presents itself with the retro-suicide paradox, where the traveller can and at the same moment cannot kill their younger version because it would contradict the very possibility of time travel (Vranas 2009: 521-522). Clearly, playing with time is an ambitious task, which determines science fiction as a genre. The paradoxes are inscribed in the time manipulations and have become the subject of a science fiction story a number of times. Polish SF authors also tackle the question of time travel and the related repercussions, both in 'pure' science fiction and in hybrids. Naturally, the most acclaimed Polish SF writer, who explored the notion of time in his work, for example in Return from the Stars (1961), is Stanisław Lem. However, another example may be provided by Andrzej Pilipiuk, an author known for fantasy, science fiction and adventure stories.

\section{Time Travel in Operacja Dzień Wskrzeszenia}

Krzysztof Piskorski enriches steampunk aesthetics with borrowings from other genres, whereas Andrzej Pilipiuk subordinates the adventure and thriller genres to the conventions of science fiction. His 2006 novel Operacja Dzień Wskrzeszenia is an SF story which does not explore futuristic states and societies, but examines the past and its influence on later developments and progress. Despite the fact that the narrative sends the main characters into the past, and the major part of the narrative takes place in previous centuries, the author never allows his readers to forget about the science fictional provenance of the story, especially in reference to time travel, which made it possible for the characters to visit the past. The point of departure of the novel is a future very close to the year of its publication, namely 2012. Due to unfortunate decisions of the Polish president, Paweł Citko, terrorists take possession of secret nuclear missiles, of which no other European country is aware. Thus, World War III breaks out and, as the reader learns indirectly from the following chapters, provokes the annihilation of the majority of the population. In 2014, a group of young people are chosen to participate in a dangerous mission aimed at changing the tragic past of mankind and saving the world from the destruction of nuclear war. In order to succeed, they are to use the advanced technology of time travel. Therefore, they travel back to the end of the 19th century to find the president's ancestor and to inject him with a modified mumps virus, which causes sterility. However, the time travel technology being unstable, it may lead to changes in the plan, for example due to the mistakes in the calculations regarding the exact time and place of the destination. As 
a result, one of the team's members is caught and interrogated, but the rescue requires one more jump in time, which takes the protagonists to the 17th century, thus leaving one colleague behind.

Pilipiuk combines contemporary references with science fictional descriptions of time travel technology and the related risks, as well as with the portrayal of different historical periods. The first part of the novel is focused upon the explanation of the specification of the mission. The students who have been chosen to accomplish the mission infer from the surroundings in the base where they are to complete their training that their employers have developed a time machine: "'So they have a time machine here,' the student mused. 'We prefer to call it a spatiotemporal communicator,' a commanding, however melodious, voice filled the room"5 (Pilipiuk 2006: 29). With reference to the observations of Katarzyna Gadomska (2002: 24), time machines are provided with different names, yet the devices always work upon the movement on the timeline. In Pilipiuk's narrative, the concept of time travel and its paradoxes are closely examined.

The first paradox emerges at the beginning of the protagonists' visit to the training base, when they notice brass plates honouring those who have sacrificed their lives in the service of the mission. The names are followed by their date of birth in the 20th century and the date of death, often located much earlier in time: "Dr Michaił Kolcow 1976-1901, Dr Jan Przeździecki 1980-1901..." (Pilipiuk 2006: 27). This is a good illustration of the paradoxes indicated by David Lewis, as quoted earlier in the text, when he muses upon so-called personal time, or the time flow for a given person, i.e. the time traveller, and external time, meaning the general timeline of history (Lewis 1976: 146). On the one hand, because of the excursion in time effected by the deceased heroes, their personal time, or the time they actually lived, equals the period between their birth and the date of their departure in the time machine with the addition of the time they had spent in the past until the day they died. On the other hand, the external time should be perceived in this particular case as disturbed, because the date of death preceding the date of birth contradicts the rules of logic.

For the safety of the participants in the project, the instructors caution them about the dangers of the time travel process. In order to increase the chance of succeeding with the task, the protagonists also learn about the details of the procedure itself (Pilipiuk 2006: 52, 55). For instance, the instructor explains that during the jump in time 'a blister' of matter is isolated from the surrounding world and the traveller needs to fit inside of it for them to be transported to their destination point. Any additional matter elements that have not been embraced by the blister would be obliterated. The blister has been adjusted to match the normal direction of the time flow, which is crucial for the traveller's natural processes. If the flow of time was not in harmony with the human organism, the traveller's body would not be able to survive the journey. This is exactly what happens to certain materials, like metals, which are destroyed in the process and, hence, are included on the list of items that cannot be equipped during time travel.

5 “ - A więc oni mają tu wehikuł czasu - zadumał się student. - Wolimy nazwę „komunikator czasoprzestrzenny” rozległ się za nimi melodyjny, acz władczy głos.” 
Nevertheless, the most important rule to remember is the one referring to the mass which can be relocated in time (Pilipiuk 2006: 51). Because of the consumed energy only seventy-five kilograms are allowed for transportation into the past and only seventy on the way back to the present moment. Any excess disintegrates or is disfigured to the extent of not being recognizable anymore. The rule is strictly connected with the explanation of the time travel process based on the analogy of a rubber band, where the rubber band stretched above the surface of the table symbolizes the present, and the table itself designates the past (Pilipiuk 2006: 65). To reach the past and to be able to return, the rubber band has to be weighed down. This is possible thanks to the use of a metal ball, which symbolizes the blister created by the time machine. The blister touches the table, or the past, which it refers to, yet it needs plenty of energy to make the return possible. The rules introduced to the story by Pilipiuk give order to the chaotic concept of time travel and help organize the narrative. Thanks to them, both readers and characters know what to expect from the experiment.

Having understood the process and risks that must be taken, the protagonists learn about the paradoxes. They discuss the grandfather paradox, the principle of non-interference, and the butterfly effect (Pilipiuk 2006: 80-83). The author provides an explanation of the grandfather paradox because in the novel it becomes a tool of completing the mission. The task is based on the assumption that the past can be changed and, therefore, the participants of the project are able to sterilize the president's ancestor, thus preventing the president from being born. Nicholas Smith (2016: online) claims that SF authors tend to introduce the figures of time guardians who control the travellers to preclude them from damaging the natural flow of time on the timeline. Pilipiuk incorporates in the novel the characters of the instructors, who warn the travellers and formulate the principle of non-interference. Hence, the protagonists must not rescue anyone in danger or interact with too many people, since even an apparently insignificant encounter may lead to a great change in history, which would influence the present moment and the future deeply. The so-called butterfly effect describes such a situation well. The analogy presents the assumption that if a butterfly flaps its wings, the gradual accumulation of wind disturbance will, in time, create a storm on the other hemisphere. If the participants of the project did not limit their interference to the past world, the negative effect would exceed the positive effect of their mission.

When the author finally sends the protagonists back in time, he never abandons the science fictional setup. History, along with the description of 19th and 17th century reality, becomes an element of the science fiction genre. In Piskorki's steampunk the setting, the background and a particular character impact upon the actions of the heroine. In Pilipiuk's SF thriller story, history constitutes a part of the time travel process. Distant and difficult to understand, the past is a stage which the protagonists need to reach in order to be able to influence the future and accomplish their goals. Nonetheless, even if history serves a slightly different purpose in science fiction than in steampunk, as shown in previous examples, the author describes historical realities diligently, for example in a scene when the characters reach the 17th century and observe the state of development of Warsaw (Pilipiuk 2006: 330-331). 


\section{Conclusions}

The described examples and theory clearly prove that both history and time define steampunk and science fiction. Consequently, the importance of time-related concepts allow the representatives of these particular genres to borrow tropes from both in order to examine the question of time flow or history in the development of nations in numerous different aspects. 19th century history, i.e. the very subject matter of steampunk, provides the authors, such as Krzysztof Piskorski, with tools which help them in investigating the notions of historical change and revolution, especially visible in the Polish, insurgence-focused version of steampunk. Surprisingly, the approach towards time and history in science fiction is both similar and different to the one found in steampunk. As the example of Andrzej Pilipiuk's work shows, it is similar because the author is interested in the continuity of history and its impact on the later periods of time. The difference consists in manipulating time, for instance in time travel, in order to manipulate actively the influence the past has on the present and the future.

\section{References}

Bernstein, Sara. 2015. Nowhere Man: Time Travel and Spatial Location. Midwest Studies In Philosophy XXXIX. 158-168. EBSCOhost, doi:10.1111/misp.12041.

Gadomska, Katarzyna. 2002. Science-fiction et fantasy comme merveilleux contemporain. Katowice: Wydawnictwo Uniwersytetu Śląskiego.

Ganapathiraju, Aishwarya. 2012. Urban Retro-Futuristic Masculinities in China Mieville's Perdido Street Station. The Journal of Popular Culture 45(1). 3-14. EBSCOhost, doi:10.1111/j.1540$-5931.2011 .00907 . x$.

Lemann, Natalia. 2015. Polski steampunk - zaadaptować historię, adaptując konwencję. In: Wioletta Hajduk-Gawron (ed.), Adaptacje II: Transfery kulturowe - Biblioteka Postscriptum Polonistycznego 5, 133-147. Katowice: Wydawnictwo Uniwersytetu Śląskiego.

Lewis, David. 1976. The Paradoxes of Time Travel. American Philosophical Quarterly 13(2). 145-152. Mielke, Tammy L., LaHaie, Jeanne. 2015. Theorizing Steampunk in Scott Westerfeld's YA Series Leviathan. Children's Literature in Education 46. 242-256. EBSCOhost, doi:10.1007/s10583-014-9232-0.

Pilipiuk, Andrzej. 2006. Operacja Dzień Wskrzeszenia. Lublin: Fabryka Słów.

Piskorski, Krzysztof. 2016. Czterdzieści i cztery. Kraków: Wydawnictwo Literackie.

Smith, Nicholas J.J. 2016. Time Travel. In: Edward N. Zalta (ed.) The Stanford Encyclopedia of Pilosophy. https://plato.stanford.edu/archives/spr2016/entries/time-travel/ (28 April 2017).

Web 1 - Emilia Plater / Dzieje.pl. http://dzieje.pl/postacie/emilia-plater-1806-1831 (27 April 2017).

Vranas, Peter B. 2009. Can I Kill My Younger Self? Time Travel and the Retrosuicide Paradox. Pacific Philosophical Quarterly 90. 520-534. EBSCOhost, doi:10.1111/j.1468-0114.2009.01353.x. 